\title{
Kerja Sama Orang Tua Dan Guru Dalam Membangun Kreativitas Siswa Madrasah Ibtidaiyah Melalui Pembelajaran Online
}

\author{
Nur Khosiah, Ari Susandi, Agustiarini Eka Dheasari \\ STAI Muhammadiyah Probolinggo \\ E-mail : nurkhosiah944@gmail.com \\ Diterima: Desember 2020 ; Dipublikasikan Januari 2021
}

\begin{abstract}
ABSTRAK
Di Era Globalisasi saat ini kerjasama Orang Tua dan Guru dalam pendidikan sangatlah amat penting agar siswa-siswi kita lebih terarah pola berfikirnya dan tidak mudah terpengaruh dengan hal-hal baru seperi HP, laptob, televisi, internet dan lain sebagainya yang mana didalamnya ada yang sesuai dengan adat ketimuran kita dan ada tidak sesuai dengan adat ketimuran bangsa kita tercinta yaitu bangsa Indonesia. Tujuan penelitian ini untuk mengetahui kerjasama Orang Tua dan Guru dalam membangun kreativitas siswa kelas 4 MI.Miftahul Ulum Tongas-Probolinggo melalui pembelajaran online. Metode dalam penelitian ini peneliti menggunakan deskriptif kualitatif. Tekhnik pengumpulan data dengan melakukan observasi, wawancara, dokumentasi.Adapun analisis data dilakukan dengan cara pengumpulan data, reduksi data, penyajian data, dan penarikan kesimpulan.Hasil penelitian menunjukkan bahwa kerjasama orang tua dan guru kelas 4 di MI.Miftahul Ulum Tambakrejo-Tongas-Probolinggo dalam membangun kreatifitas siswa yaitu dengan selalu berkomunikasi melalui HP (telp, wa, sms, videocall), saling mengadakan kunjungan kerumah wali murid dan sebaliknya, mengadakan rapat seminggu sekali atau dua minggu sekali untuk mengevaluasi proses kerjasama yang di lakukan, saling memberikan semangat antara guru kelas 4 dan wali murid.
\end{abstract}

Kata Kunci: Kerjasama Orang Tua dan Guru, Kreativitas siswa, Pembelajaran Online

\begin{abstract}
In the current era of globalization, the collaboration between parents and teachers in education is very important so that our students are more focused on their thinking patterns and are not easily influenced by new things such as cellphones, PC, television, internet and many others, which contain something in accordance with our eastern customs and there are not in accordance with the eastern customs of our beloved nation, namely the Indonesian nation. The purpose of this study was to determine the cooperation of parents and teachers in building the creativity of 4th grade students of MI. Miftahul Ulum Tongas-Probolinggo through online learning. The researcher used a qualitative descriptive method in this study. The technique of collecting data are observing, interviewing, and documenting. The data analysis is done by collecting data, reducing data, presenting data, and drawing conclusions. The results showed that the collaboration between parents and teachers of grade 4 at MI Miftahul Ulum Tambakrejo-Tongas-Probolinggo in building student creativity, namely by always communicating via cellphones (phone, wa, sms, videocall), come to the parents of students and also hold a meeting once a week or every two weeks to evaluate the collaboration process that is being carried out, giving mutual encouragement between teachers of grade 4 and student guardians in the class.
\end{abstract}

Keywords: Parents and Teachers 'Collaboratin, Students 'Creativity, Online Learning

\section{PENDAHULUAN}

Orang tua adalah Orang yang telah mengasuh, membimbing, mengarahkan, memberikan keteladanan dan yang telah memberikan kasih sayang tak terhingga dalam kehidupan sehari-hari yaitu ibu dan ayah kita tercinta. Orang tua wajib kita hormati, kita junjung setinggi-tingginya karena beliau adalah orang yang telah memberikan segalanya demi kelangsungan hidup kita untuk itu mereka akan memberikan pendidikan yang terbaik untuk kita baik melalui sekolah formal maupun non formal. Sebagaimana yang di ungkapkan oleh (Gordon:1984) bahwasannya Orang Tua yang efektif akan tetap membiarkan dirinya 
sebagai pribadi sejati. Dan anak-anak lebih menghargai sifat manusiawi dan tidak berpurapura ataupun berbohong pada orang tua.

Pendidikan utama berada di rumah bersama keluarga Karena waktu di rumah lebih banyak dari pada di sekolah formal ataupun nonformal. Sehingga peran orang tua sangat menentukan pendidikan anak-anak mereka mau di bawah kemana dan di arahkan kemana putra-putri mereka. Yang jelas peran orang tua sangat menentukan masa depan mereka. Perilaku putra-putra kita mayoritas meniru apa yang dilihatnya terutama di rumah, meski tidak dapat di pungkiri lingkungan sekitar juga dapat mempengaruhi mereka akan tetapi jika dari rumah sudah di bekali dengan pondasi yang baik, pendidikan yang baik, keteladanan yang baik tentu pengaruh dari luar tidak akan langsung berpengaruh kepada mereka akan tetapi anak-anak kita akan menfilternya terlebih dahulu. Berbeda dengan kondisi keluarga atau orang tua yang perannya tidak sebagaimana mestinya sebagai orang tua tentu hasilnyapun akan berbeda dengan orang tua yang peran dalam keluarganya maksimal kepada anak-anaknya.Jika dalam keluarga, perilaku orang tuanya hanya memasrahkan pendidikannya kepada pihak sekolah atau guru-guru yang ada di sekolah tanpa memberikan perhatian dan kasih sayangnya pada anak tentu anak ini akan mengalami perasaan merasa tidak di perhatikan yang akhirnya anak seperti ini akan melakukan hal-hal sesuai dengan keinginannya tanpa memikirkan masa depan yang akan di hadapinya kelak.

Pendidikan sekolah sifatnya hanya membantu anak-anak kita dari segi pendidikan secara kognitif saja akan tetapi dari segi afektif dan psikomornya lebih banyak mengadopsi pada lingkungan dimana ia lebih banyak menghabiskan waktunya bersama. Akan tetapi peran sekolah dan guru juga sangat penting sekali karena terkadang perilaku guru, perkataan guru, cara berpakaian guru, cara berbicara guru dan lain-lain menjadi idola bagi anak-anak kita terutama anak usia sekolah dasar.

Pendidikan di era globalisasi ini benar-benar harus mendapat pengawasan dari pihak keluarga karena dengan hadirnya tehnologi yang serba canggih akan memudahkan anakanak kita mendapatkan pengetahuan yang luas melalui berbagai macam media dan juga akan memudahkan anak-anak kita kepada hal-hal baru yang tidak sesuai dengan agama yang kita anut dan juga terkadang banyak indikasi memecah persatuan dan kesatuan bangsa Indonesia.

Untuk ityu saebagai orang tuan dan guru harus banyak mengajarkan rasa persatuan dan kesatuan bangsa, cint tanah air, toleransi beragama agar tidak mudah terprofokasi dengan isu-isu yang menginginkan perpecahan. Sebagaimana yang disampaikan oleh . (Suardana, 2020)

Sesuai dengan sila yang pertama yaitu "Ketuhanan Yang Maha Esa". Dan yang menjadi ideologi nasional negara ini, Pancasila yang menyatakan keyakinan kepada hanya satu Tuhan. Dan kita semua sebagai warga negara Indonesia wajib setia kepada bangsa Indonesia dan ideologi Pancasila.

Bangsa Indonesia saat ini mengalami pandemi Covid -19 dan bukan hanya bangsa Indonesia akan tetapi semua bangsa di dunia mengalami pandemi Covid-19. Semua bangsa di dunia mempunyai kebijakan berbeda dalam menangani wabah ini. Di Indonesia khususnya semua warga wajib pakai masker, jaga jarak, cuci tangan dan harus mematuhi protokol kesehatan. jika tidak mematuhi akan di tindak sesuai dengan kebijakan masingmasing daerah yang ada di Indonesia. Dalam dunia pendidikan seiring perkembangan tehnologi yang cukup pesat mungkin ini saatnya kita harus dapat memanfaatkan telefon genggam (HP) bukan hanya sekedar berkomunikasi dengan keluarga atau relasi akan tetapi sekarang waktunya untuk di manfaatkan sebagai media pembelajaran karena kondisi pandemi covid-19. Banyak tempat yang kini menyediakan internet secara gratis, baik lingkungan pemerintahan maupun dilingkungan swasta ataupuntempat umum, bahkan juga menjadi bisnis yang menggiurkan seperti di warung kopi atau tempat dagang lainnya yang seolah sudah menjadi wajib untuk mendapatkan pelanggan yang banyak. Akan tetapi kita tidak boleh lupa dengan dampak negatif yang di timbulkan makhluk yang bernama internet ini, kita harus menggunakan sesuai dengan kebutuhan bukan sesuai keinginan nafsu manusia. 
Sebagaimana pendapat (Solviana, 2020) Kehidupan saat ini telah memasuki era penggunaan media internet yang semakin canggih dan selalu terkoneksi. Masyarakat di jejali dengan berita yang sangat berlimpah terkadang sampai bingung sendiri di buatnya. Inilah perkembangan tehnologi ada yang membawa baik akan tetapi dampak burukpun juga banyak jika kita tidak bijaksana dalam penggunaannya. Untuk itu dalam dunia pendidikan memerlukan kerjasama antara pihak orang tua dan guru/ sekolah agar anak-anak kita dapat memanfaatkan benar-benar manfaat untuk kehidupan sehai-hari dan masa depan mereka bukan hanya sebagai media hiburan dan lain sebagainya.

\section{METODE PENELITIAN}

\section{Jenis Penelitian}

Penelitian ini bertujuan untuk mengetahui kerjasama orang tua dan guru dalam membangun kreativitas siswakelas 4 di MI.Miftahul ulum Tambakrejo Kec, Tongas Kab. Probolinggo. Penelitian ini di lihat dari tempatnya merupakan penelitian lapangan yaitu penelitian yang menggunakan dan mengambil subyek yang diteliti. Pada penelitian yang dilakukan ini berjenis penelitian kualitatif, yaitu penelitian yang bertujuan untuk memahami kerjasama yang dilakukan oleh orang tua dan guru, untuk menganalisis, mendeskripsikan, mencatat dan mengiterpretasikan keadaan nyata yang sedang terjadi. (Nurhayati, 2020)

\section{Sumber data dan tehnik pengumpulan data}

Sumber data penelitian ini di dapat dari guru kelas 4 M.I Miftahul Ulum dengan siswa yang sejumlah 24 siswa dan wali murid atau orang tua dari siswa kelas 4. Dari sumber data tersebut peneliti menggali informasi yang berkaitan dengan kerjasama yang dilakukan oleh orang tua dan guru kelas 4 dalam membangun kreativitas siswa melalui pembelajaran daring/ online. Data lainnya di dapat dari Kepala sekolah dan rekan kerja lainnya.

Peneliti melaksanakan penelitian ini antara bulan agustus 2020 sampai Oktober 2020 dan mewawancarai kepala sekolah, guru kelas IV dan wali murid kelas IV sehingga terkumpul informasi dan data awal tentang kerjasama yang dilakukan orang tua siswa kelas IV dan guru kelas IV. Dalam hal pengumpulan data, tehniknya antara lain observasi, wawancara, dan dokumentasi. Pertama observasi adalah mengumpulkan data melalui pengamatan dan mencatat setiap keadaan atau perilaku pada objek yang diteliti (Oktifuadi:2018). tehnik pengumpulan data melalui pengamatan dengan mencatat apa saja yang dilakukan oleh guru kelas 4 dan orang tua dalam proses kerjasama. Kedua wawancara yaitu teknik pengumpulan data dengan menggunakan cara tanya jawab dengan cara tersistematis sesuai denga tujuan ( Meria :2015.). Wawancara dilakukan kepada kepala sekolah , guru kelas IV dan wali murid kelas 4. untuk menggali informasi tentang kerjasama yang di lakukan dalam menghadapi masa pandemi dengan melalui pembelajaran daring/ online. Ketiga adalah dokumentasi yaitu suatu informasi yang diperoleh dengan bentuk gambar atau tulisan( Meria : 2015.) peneliti menggunakan tehnik dokumentasi ini untuk memperoleh data tambahan mengenai beberapa data tertulis atau gambar tentang kerjasama yang dilakukan oleh orang tua dan guru kelas 4 di MI Miftahul Ulum Tambakrejo - Tongas - Probolinggo.

\section{Tehnik Analisis Data}

Tehnik analisis data di gunakan untuk mendapatkan kesimpulan dan jawaban yang sistematis maka data dari hasil observasi, wawancara dan dokumentasi dilakukan dengan langkah-langkah sebagai berikut:

a. Reduksi data

Dalam reduksi data ini merupakan pemilihan hal penting danpokok sehingga dapat memudahkan peneliti mengumpulkan data yang berkenaan dengan kerjasama orang tua dan guru kelas 4 dalam membangun kreativitas siswa di masa pandemi covid 19.

b. Penyajian Data

Penyajian data yaitu memilih data sesuai dengan apa yang di butuhkan tentang kerjasama yang dilakukan antara orang tua danguru kelas 4 di MI Miftahul Ulum Tambakrejo Tongas - Probolinggo. 
c. Penarikan Kesimpulan

Penarikan kesimpulan yang dilakukanoleh peneliti dengan beberapa bukti penelitiann lapangan di nmasa pandemi denga melalui pembelajaran daring/ Online.Selanjtnya mendeskripsikan data yang di perolah dandi analisis secar cermat dan sistematis. (Sujadi, 2015)

\section{HASIL DAN PEMBAHASAN}

\section{Peran Orang Tua dan guru dalam membangun kreatifitas siswa melalui pembelajaran online}

1. Peran Orang Tua dalam membangun kreatifitas siswa melalui Pembelajaran online

Keluarga merupakan bentuk masyarakat kecil yang terdiri dari ayah, ibu dan anak. Keluarga juga merupakan kesatuan terkecil dari masyarakat. Pendidikan pertama dan paling utama adalah keluarga karena orang tualah yang menjadikan anak itu menganut agama dan berperilaku seperti apa, semua bergantung kepada pendidikan awal di dalam keluarga. Sebagaimana yang diungkapkan Ahmadi dan Uhbiyati (1991:176) bahwasannya Anak dilahirkan ke dunia ini dalam pemeliharaan orang tuanya tanpa ada yang memerintahkan kepada orang tua untuk memikul tugas sebagai pendididk, baik yang bersifat pemelihara, sebagai guru, seagai pengasuh, sebagai pembina, sebagai pembimbing, sebagai guru dan pemimpin terhadap anak-anaknya. Ini adalah tugas kodrati dari tiaptiap manusia.

Peran keluarga terutama orang tua terutama peran seorang ibu yang menjadi wadah dari si anak, ibu mengandung selama 9 bulan, inipun sudah mendapatkan pendidikan dari orang tua terutama ibu misalkan mengerjakan sholat lima waktu dengan tepat waktu, tentu ini sudah mengajarkan kedisiplinan, sering mengelus-elus perutnya ini sudah mengajarkan kasih sayang pada si anak, cinta akan kebersihan dan lain sebagainya. Perilaku seperti contoh yang disebutkan ini setelah anak terlahir akan berpengaruh pada diri anak tersebut apalagi setelah di lahirkan ibu menyusuhinya sampai usia 2 tahun. Tentu yang lebih dominan pada umumnya yang menentukan karakter dan kreatifitas seorang anak adalah ibu. Peran ibu pada pendidikan anak sangat penting apalagi biasanya seorang anak lebih dekat dengan ibunya karena ibulah yang mengasuhnya sedangkan ayah mencarikan nafkah untuk istri dan anak-anaknya. Antar ibu danayah harus ada sinergi yang berkesinambungan dalam pendidikan anak-anaknya.

Keterlibatan orang tua dalam pendidikan anak dapat diidentifikasi dalam beberapa pola seperti kerjasama orang tua dan anak ketika di rumah misalnya, membantu pekerjaan rumah, bersihbersih rumah, menyiram tanaman, membantu memasak, sedangkan kegiatan berbasis sekolah misalnya, menghadiri acara sekolah, menanyakan pada guru kehadiran anaknya, saling berkomunikasi tentang pelajaran di sekolah, serta pemantauan perilaku anak-anak di luar sekolah. Di era berkemajuan saat ini, dari segala bidang mengalami perkembangan dan kemajuan terutama terutama bidang tehnologi informasi dan komunikasi yang awalnya hanya ada HP untuk sms dan telp saja akan tetapi sekarang sudah ada berbagai aplikasi yang memudahkan seseorang untuk mengakses pengetahuan, perekonomian, sejarah, dan lain sebagainya dengan melalui internet. Apalagi pada masa pandemi saat ini melalui internet, HP, laptob bisa digunakan meski tanpa bertatap muka dengan orang yang di ajak bicara. Dan inilah saatnya orang tua berperan menjadi seorang pengajar di rumah untuk mengerjakan tugas dari guru di sekolah dan membangun kreatifitas anak dalam pembelajaran daring/ Online karena tanpa pengawasan orang tua tentu anak-anak kita tidak akan mengerjakan tugas yang di sampaikan guru melalui HP, apalagi anak tingkat Madrasah Ibtidaiyah/ Sekolah Dasar yang notabenya masih sangat membutuhkan bimbingan, pendampingan maupun pengawasan.

Di Era pandemi covid -19 semua sekolah mulai dari tingkat Dasar sampai perguruan Tinggi melakukan pembelajaran daring/ Online. Pembelajaran daring sebagai salah strategi pembelajaran online yang dilakukan oleh setiap sekolah dalam masa pandemi covid -19 disebabkan belum di perkenankan melakukan tatap muka pada setiap lembaga pendidikan. Akan tetapi dengan strategi pembelajaran daring/ Online ini siswa akan merasa senang dan menyenangkan melalui HP android, Laptob, Komputer bukan hanya membaca atau menyimak di buku ataupun mendengarkan keterangtan guru. Pembelajaran daring/ Online merupakan sebuah peluang bagi lembaga pendidikan agar mengembangkannya secara berkelanjutan sebagai moment peralihan dari pembelajaran secara 
konvensional. Ini berarti pembelajaran online ini tidak berakhir pada masa pandemi saja akan tetapi tetap di lanjutkan dan di kaji, di evaluasi dalam meningkatkan kreatifitas anak dan mewujudkan efektifitas pembelajaran. (Ayubi, 2020)

\section{Peran Guru dalam membangun kreatifitas siswa melalui pembelajaran Online}

Guru merupakan orang tua kedua setelah orang tua kandung kita dirumah. Guru adalah orang yang harus kita junjung martabatnya karena beliau telah memberikan bimbingannya dari orang yang tidak tahu menjadi tahu, dari tidak bisa menjadi bisa. Guru mempunyai peran yang sangat penting dalam sendi kehidupan terutama dalam bidang pendidikan dan pengajaran. Guru pada Madrasah Ibtidaiyah/ Sekolah Dasar tentunya sudah menyadari bahwa dirinya menjadi suri tauladan bagi peserta didiknya baik dari segi cara berpakaian, cara berbicara, cara bersikap, cara bergaul, dan lainlain tentu ini akan menjadi tuntunan terbentuknya karakter dalam kehidupan sehari-hari peserta didik. Apalagi jika menjadi seorang guru di pedesaan atau di pedalaman daerah benar-benar menjadi model/ figur yang di idolakan oleh peserta didik dan juga orang tua dari peserta didik sebagaimana pepatahmengatakan " guru di gugu lan di tiru" jadi segala perilaku guru menjadi panutan anak dan orang tua maupun masyarakat.

Guru di tuntut menjadi pribadi yang sempurna sesuai ajaran Islam dan guru juga harus dapat mengerti kondisi peserta didik dengan berbagai macam karakter untuk itu sesuai dengan pendapat Departemen Agama Republik Indonesia (1996;2) Guru hendaknya menguasai teori-teori perkembangan Anak agar dapat memahami ciri khas masing-masing anak dan prestasi yang di capainya dan guru juga dapat memilih sumber, alat, bahan pembelajaran dan metode, tehnik, strategi pembelajaran yang tepat sehingga dapat menciptakan lingkungan belajar kondusif, menarik dan bermakna. Apalagi menghadapi zaman berkemajuan saat ini, kecanggihan tehnologi tersedia di segala bidang, untuk bidang pendidikan sekarang ini ada makhluk yang bernama internet dapat mempermudah segalanya melalui HP Android, laptob, komputer dapat mengakses pengetahuan yang di inginkan. Sebelum masa pandemi covid-19 guru dapat mengajarkan secara langsung apa adanyabaik iytu tehik, strategi ,alat deanmedia bisalagsung di tunjukkan sebagaimana yang di terangkan oleh (Solviana, 2020) bahwasannya penggunaan multimedia sudah banyak dilakukan dalam pembelajaran contohnya penggunaan video dan audio, animasi, teks, gambar dan lain sebagainya agar dapat memotivasi dan menarik peserta didik lebih menyukai materi yang di ajarkan oleh guru.

Pendapat lain menyatakan bahwa belajar memerlukan intensitas tinggi yang di dasarkan pada adanya motivasi siswa. Intensitas merupakan realitas dari motivasi dalam mencapai tujuan yang di harapkan yaitu meningkatnya prestasi siswa, sebab orang melakukan usaha dengan penuh semangat karena ada motivasi sebagai pendorong tercapainya prestasi (Mumu et al., 2019). Untuk itu peran guru sangat mendominasi dalam dunia pendidikan. Di lembaga - lembaga pendidikan, Ada sekolah favorit sehingga muridnya banyak sampai ruang kelas tidak mencukupi dan ada juga sekolah yang di marger karena sarana prasaran serta gurunya dianggap belum kompeten atau tidak sesuai dengan jurusan dalam mengajarnya, sehingga dari berbagai kalangan menganggap belum mampu melahirkan alumni yang berkualitas. Pendidikan disekolah belum sepenuhnya menghasilkan insaninsan terdidik dan beretika (Suardana, 2020)

Apalagi di era pandemi covid-19 saat ini yang semua harus dituntut untuk belajar dari rumah, dari sini tugas guru semakin berat harus dapat menciptakan dan membangun pembelajaran yang menarik meski pembelajaran di lakukan secara daring/ Online tidak tatap muka. Hal ini menjadi tantangan bagi setiap guru agar dapat menciptakan dan membangun kreatifitas peserta didik dalam masa pandemi saat ini. Pembelajaran daring, tentu akan sulit dilakukan jika tidak ada pendampingan dari pihak keluarga untuk itu di masa pandemi covid- 19 ini orang tua dan guru harus bersinergi dalam membimbing anak-anak mereka. Guru dan orang tua harus mampu meningkatkan keaktifan dan kreativitas siswa di masa pandemi covid-19.

Keaktifan dan kreatifitas siswa dapat tercipta melalui penerapan media pembelajaran yang menarik. Dengan banyaknya aplikasi yang sudah tersedia dalam HP android, Laptob, maupun komputer merupakan salah satu media pembelajaran yang menarik dalam pembelajaran daring dengan melalui via zoom, google classroom, dan lain sebagainya. contohnya memanfaatkan game edukasi quiziz dan yang lainnya, ini akan dapat menambah ketertarikan dan minat siswa pada 
pembelajaran online, karena pembelajaran online dapat dilakukan dimanapun mereka berada. (Nurhayati, 2020). (Abidin et al., 2020) menjelaskan bahwa Pembelajaran online tentunya akan lebih bermakna strategi dan metode pembelajaran yang tepat. Contoh lain penerapan pembelajaran online adalah pembelajaran berbasis proyek ini dapat memberikan peluang kepada wiswa untuk mempelajari konsep secara mendalam dan dapat meningkatkan hasil belajar mereka.

pendapat yang sama juga di jelaskan oleh (Ayubi, 2020) bahwasannya situasi dan kondisi pandemi saat ini menuntut para pendidik untuk dapat menciptakan sesuatu yang baru atau kreatifitas pendidik dalam penerapan pembelajaran daring/ online sesuai dengan yang diharapkan. Untuk itu peran pendidik sangat penting dalam masa pandemi covid -19 saat ini agar siswa dapat membangun kreativitasnya meski tanpa bertatap muka. Dalam pelaksanaannya tentu para pendidik ini seperti guru, dosen membutuhkan desain atau perencanaan dan strategi yang tepat untuk memulai pembelajaran daring.

\section{Kreativitas Siswa Dalam Pembelajaran Online}

Setiap anak terlahir ke dunia ini dalam keadaan fitrah, keluarganyalah yang nantinya akan menjadikan dia sesuai dengan harapan keluarganya. Setiap anak juga memiliki kelebihan dan kekurangan masing-masing, akan tetapi orang tualah yang dapat mengarahkan ke depan si anak bercita - cita menjadi apa, di bantu dengan guru di sekolah anak akan menemukan apa yang menjadi bakatnya. Setiap anak memiliki kreativitas, sesuatu/ bakat yang baru pada dirinya. Sebagaimana yang di jelaskan (Issa, 2019) bahwasanya Kreativitas merupakan kemampuan seseorang yang dikaitkan dengan prestasi istimewa dalam menciptakan hal-hal yang baru atau hal yang sudah ada menjadi konsep baru, menemukan cara/ solusi dalam pemecahan masalah, membuat ide-ide baru yang belum pernah ada, dan melihat berbagai kemungkinan yang akan terjadi.

Kerativitas dalam pendidikan sangat diperlukan. Sudah saatnya dunia pendidikan mempertimbangkan aspek kreativitas pendidiknya maupun peserta didiknya di era globalisasi yang penuh dengan persaingan seperti sekarang ini. Pentingnya kreativitas pada peserta didik ini akan dapat menghadapi kondisi zaman yang semakin berkemajuan, apalagi dalam era pandemi covid-19 , semua aktivitas pendidikan berada di rumah atau belajar dari rumah melalui pembelajaran daring/ Online, sebagai seorang pendidik harus dapat meningkatkan dan membangun kreativitas poeserta didik yang dapat dibuktikan dengan hasil karya baru atau sesuatu yang baru karena pada dasarnya setiap siswa memiliki potensi berkembang untuk menjadi lebih baik, kreatifitasnya, pola fikirnya, perilakunya, perbedaannya hanya terletak pada bidang yang di ekspresikan dan di jalankan.

Seorang anak pasti memiliki kreativitas yang tinggi meski tidak semua siswa di MI.Miftahul Ulum tambakrejo Kecamatan Tongas Kabupaten Probolinggo memilikinya. Akan tetapi yang jelas tidak ada seorang anakpun yang tidak memiliki kreativitas, seorang guru harus yaqin pada setiap siswa MI.Miftahul Ulum khususnya kelas IV bahwa siswa- siswa mereka kreatif, hanya saja bagaimana kita sebagai seorang guru merangsang kreativitas mereka. Sebagaimana yang di ungkapkan oleh (Issa, 2019) bahwasannya kreativitas anak harus dirangsang terlebih dahulu terutama dari linkungan dia berada sebab berbeda dengan dengan orang dewasa, kreativitas anak dikorodori oleh keunikan gagasan yang terkadang kita belum dapat menelaahnya dikarenakan adanya imajinasi dan fantasi pada diri siswa Madrasah ibtidaiyah atau Sekolah Dasar artinya mereka memiliki kebebasan dan keluasan beraktivitas dan berkreasi.

Seorang anak dikatakan kreatif apabila ia telah memenuhi syarat fluency (memunculkan ide alternatif) dan flexibility (konteks berbicara memilih solusi yang baik) dalam pemecahan masalah meski itu terilhami dari pengalaman orang lain. (Issa, 2019) mengungkapkan bahwa anak yang dapat menyelesaikan masalahnya sendiri disebut kreatif,meski solusinya diilhami oleh pengalaman orang lain, dalam hal ini, originalitas bukan faktor utama kreativitas seorang anak. Di Era berkemajuan saat ini tehnologi informasi dan komunikasi, internet menjadi sarana komunikasi interaktif antara pendidik dan peserta didik, apalagi pada masa pandemi covid-19 ini,

Setiap lembaga pendidikan pada masa pandemi covid -19 ini menerapkan program pembelajaran online ini akan memberi peluang besar kepada peserta didik untuk lebih kreatif dan mandiri. Dengan kata lain, pembelajaran daring ini melatih anak-anak kita unk lebih mandiri dan dapat membangun kreativitasnya masing-masing sesuai kemampuannya yang disajikan dalam bentuk digital dan tersimpan.(Ayubi, 2020). Pembelajaran daring/ online merupakan pembelajaran 
jarak jauh tanpa kontak fisik namun dapat berkomunikasi, berinteraksi dan berkaloborasi antara guru atau pendidik dengan peserta didiknya. Pembelajaran online memanfaatkan teknologi telekomunikasi dan informasi dengan internet melalui HP Android, laptob, komputer dengan berbagai aplikasi yang dapat di gunakan dalam pembelajaran daring/ online seperti zoom, google claasroom dan lain-lain.

Hal yang terpenting dalam penerapan pembelajaran Online pada siswa Madrasah ibtidaiyah atau Sekolah Dasar yaitu dengan memperhatikan berbagai aspek agar tujuan pembelajaran tercapai antar lain: (1) Materi yang disajikan memiliki relevansi dengan tujuan pembelajaran (2) menggunakan metode, strategi pembelajaran yang tepat melalui contoh dan latihan-latihan untuk membantu proses belajar, (3) menggunakan media seperti gambar-gambar dan power point dalam penyajian materi dan (4) mengembangkan dan membangun pengetahuan dan keterampilan baruuntuk meningkatkan kreativitas siswa. (Abidin et al., 2020)

\section{Kerjasama Orang Tua Dan Guru dalam membangun Kreativitas Siswa melalui Pembelajaran Online}

Dalam kehidupan, setiap orang saling membutuhkan antara yang satu dengan yang lainnya untuk itu setiap orang memerlukan kerjasama karena dengan adanya kerjasama akan terpenuhi apa yang dan diinginkan oleh masing-masing pihak. Keluarga merupakan lembaga terkecil yang beranggotakan ayah, ibu dan anak. Dalam keluarga juga harus saling bekerjasama agar jika ada permasalahan atau kesulitan dapat teratasi dengan baik dan tidak ada kesalahpahaman antar anggota keluarga. Dalam pendidikan anak-anaknya orang tua juga menginginkan yang terbaik untuk itu orang tua menitipkan anak-anak mereka pada lembaga formal dalam hal ini sekolah.

Sekolah merupakan kelanjutan pendidikan yang sudah di berikan oleh orang tua pada anakanak mereka. Agar mendapatkan hasil yang di inginkan atau yang di cita-citakan dan diharapkan orang tua biasanya mengadakan kerjasama dengan guru kelas masing-masing yang ada di sekolah atau madrasah. Kerjasama orang tua dan guru biasanya akan terjalin dengan sendirinya bagi orang tua yang benar-benar memperhatikan pendidikan anak-anak mereka. Menurut pendapat ahli bahwa kerjasama antara orang tua dan guru merupakan usaha sekolah/guru dalam membimbing putra-putri dalam pendidikan yang bertujuan untuk meningkatkan dan mengembangkan pendidikan yang lebih baik lagi. Kerjasama ini bisa berupa partisipasi dan keterlibatan. (Mumu et al., 2019)

Keterlibatan orang tua dengan sekolah seperti keberhasilan sekolah, dikelas rendah ada pengulangan atau tidak pada siswa, tingkat drop-out yang lebih rendah atau tidak ada sama sekali, tingkat kelulusan dan ketepatan waktu pada studi, serta partisipasi dalam program pendidikan yang lebih tinggi. Mengingat pentingnya kerja sama sekolah dengan masyarakat hendaknya pihak sekolah dapat mengembangkan hubungan yang baik. Banyak orang yang mengartikan hubungan sekolah dan masyarakat itu dalam pengertian yang sempit. Mereka berpendapat bahwa hubungan kerja sama itu hanyalah dalam hal mendidik anak belaka bukan hal yang lain Padahal orang tua dan guru harus dapat bekerjasama agar apa yang mereka harapkan dari anak-anak terwujud nyata.

Sebagaimana yang di jelaskan Daradjat (2000:76) bahwa bentuk kerjasama orang tua dan guru adalah (1) Menanyakan keaktifan anak dan nilai mata pelajaran (2) menghadiri surat panggilan bila ada surat dari sekolah (3) Mengadakan kunjungan pada guru baik ke sekolah maupunke rumah guru (4) Menghadiri pertemuan rapat dari sekolah (5) Orang tua dan guru bersinergi memahami anak didik. Sebelum masa pandemi covid 19 kelima hal di atas selalu dilakukan oleh orang tua atau wali murid kelas 4 MI.Miftahul Ulum Tambakrejo- Tongas- Probolinggo.

Bentuk kerjasama sekolah dan orangtua yang dapat dilakukan dengan komunikasi, parenting, keterlibatan orangtua pada pembelajaran anak di rumah, cara pengambilan keputusan, dan cara berkolaborasi dengan kelompok masyarakat. Keterlibatan orangtua dalam pendidikan mempunyai berbagai bentuk dari yang sederhana yaitu menanyakan kemajuan anak di sekolah, partisipasi dalam evaluasi program, dan pembuatan keputusan dalam program (Mumu et al., 2019)

Akan tetapi pada masa Pandemi saat ini berdasarkan hasil wawancara dengan Guru wali kelas 4 dan para wali murid kelas 4 dalam membangun kreativitas siswa kelas 4 MI.Miftahul Ulum Tambakrejo Kec. Tongas Kab.Probolinggo sebagai berikut : 
"Guru kelas 4 menyatakan bahwa kerjasama yang dilakukan dengan orang tua pada masa pandemi covid-19 saat ini dengan berkomunikasi lewat HP misalnya menanyakan aktifitas di rumah tentang belajarnya, karena saat ini semua aktivitas di sekolah melakukan pembelajaran daring/ Online. Melakukan luring secara bergantian dari rumah siswa ke rumah siswa yang lainnya dari kelas 4. Berkunjung ke rumah siswa bila mana ada siswa yang tidak mengumpulkan tugas online.”

Berdasarkan wawancara yang peneliti lakukan dengan wali murid kelas 4 adalah

"wali murid Aini mengatakan bahwa kerjasama yang dilakukan dengan guru kelas 4 selaku wali kelas 4 yaitu berkomunikasi melalui HP, menanyakan kehadiran anak, keaktifan anak dalam kelas atau ketika melaksanakan zoom, berkunjung ke rumah guru jika ada tugas online yang sulit dikerjakan."

"Wali murid Asia mengatakan kerjasama yang dilakukan dengan guru dalam membangun kreatifitas siswa melalui pembelajaran daring/online : bekomunikasi dengan HP, menanyaka tugas anak dan prestasi yang capai, menanyakan tugas anak terkait prestasinya, tanya jika ada tugas yang tidak dimengerti, ketentuan mengumpulkan tugas pembelajaran daring, berkunjung ke rumah guru jika ada kesulitan dalam pembelajaran daring".

"Wali murid Mamad mengatakan kerjasama yang dilakukan dengan guru kelas 4 antara lain dengan berkunjung ke rumah guru kelas 4 , berkomunikasi melalui telp terkait nilai maya pelajaran dan nilai perilakunya ketika pembelajaran berlangsung via zoom, ketepatan waktu dalam mengerjakan tugas, pemahaman siswa pada saat menerima tugas.

"wali murid Ozi kerjasama yang dilakukan dengan guru kelas 4 yaitu dengan berkunjung kerumahnya karena rumahnya berdekatan jadi dalam seminggu bisa sampai $3 \mathrm{X}$ sampai $5 \mathrm{X}$, menanyakan jika ada kesulitan dalam pembelajaran daring/ Online maupun jika ada tugas dari guru kelas 4.

"Dari hasil wawancara denganWali Murid Rizqi kerjasama yang dilakukan antara lain selalu berkomunikasi melalui HP dengan guru kelas 4 , saling berkunjung antara guru kelas 4 dan wali murid rizqi, mengadakan pertemuan rapat dalam tiap sebulan sekali.

" wali murid intan mengatakan bahwa kerjasama yang dilakukan dengan guru kelas 4 Madrasah Miftahul ulum kec. Tongas kabupaten Probolinggo dengan menjalin silaturahmi lewat Watshap, telp, maupun videocall dalam kesehariannya, saling berkunjung ke rumah wali murid dan guru kelas 4.

Hal pertama yang harus dilakukan dalam kerjasama antara guru kelas 4 dengan orang tua siswa melalui komunikasi dengan HP android atau berkunjung ke rumah atau dengan mengupayakan program pertemuan wali yang bisa di lakukan seminggu sekali, dua minggu sekali, yang nantinya akan di jelaskan kesepakatan yang harus dilakukan terkait pembelajaran daring di era pandemi covid 19 ini. Selain itu, komunikasi juga berguna untuk menyampaikan kondisi anak, apakah anak alergi dengan makanan atau benda tertentu, kebiasaan anak, kesulitan anak, bakat dan minat anak, ikut membantu kegiatan rutinitas sekolah, dan menjaga keamanan sekolah. Sekolah yang menganggap orangtua sebagai pasangan atau rekan kerja yang penting dalam pendidikan

Kehidupan kini begitu terkoneksi dan memasuki era pemakaian yang semakin hari semakin canggih. Masyarakat dicekoki dengan informasi berlimpah yang hanya sejauh ujung jari. Akan tetapi, perkembangan teknologi ini dapat membawa dampak buruk jika tidak bijak dalam menggunakannnya.(Solviana, 2020). Kerjasama orang tua dan guru dalam kondisi seperti sekarang ini sangat penting sekali dilaksanakan sebagaimana yang di katakan oleh . (Mumu et al., 2019) bahwa Kerjasama orang tua dan guru/ sekolah dapat memberikan pengaruh pada keberadaan mereka sebagai bagian dari masyarakat sosial. Yang pada akhirnya dapat memberi semangat dan mendorong mereka untuk mampu mengeksplorasi bakat, kemampuan, dan sikap dalam menanggapi tantangan global.

Kerjasama orang tua dan guru dalam membangun kreativitas siswa kelas 4 melalui pembelajaran daring di MI.Miftahul Ulum Tambakrejo - Tongas - Probolinggo sangat penting dalam kehidupan sehari-hari karena dapat termotivasi belajar lebih giat lagi dan lebih meningkatkan ketrampilan mereka dalam menghadapi masa depan di tengah wabah pandemi covid-19 dan dengan kerjasama juga menunjukkan keberhasilan pendidikan anak-anak mereka karena dengan mengadakan kerjasama anak-anak kita lebih terarah pola pikirnya meski masih dala tingkat Madrasah Ibtidaiyah/ Sekolah Dasar. 


\section{Hambatan -Hambatan dalam Pembelajaran Online}

Setiap aktivitas sedikit banyak akan mengalami kendala/ Hambatan di dalamnya. Di masa pandemi covid-19 pembelajaran melalui daring / online yang di lakukan MI.Miftahul Ulum Tambakrejo Kec. Tongas Kab. Probolinggo juga mengalami beberapa kendala antar lain:

(1) Siswa yang tidak punya HP Android sehingga dalam pembelajaran harus pinjam pada family atau teman yang lain

(2) Kehabisan Pulsa Data

(3) Jaringan yang kurang bagus sehingga jika melakukan zoom tidak dapat mengikuti secara maksimal. Dalam permasalahan internet dan jaringan (Abidin et al., 2020 ) menjelaskan jika pembelajaran online tidak di dukung jaringan yang bagus tentu pembelajaran tidak akan optimal.

(4) HP yang Ramnya kurang besar sehingga jika ada tugas video tidak dapat mengirim video Wali murid yang belum bisa mengoperasikan HP Android

\section{KESIMPULAN}

Pendidikan di era globalisasi ini benar-benar harus mendapat pengawasan dari pihak keluarga karena dengan hadirnya tehnologi yang serba canggih akan memudahkan anak-anak kita mendapatkan pengetahuan yang luas melalui berbagai macam media dan juga akan memudahkan anak-anak kita kepada hal-hal baru yang tidak sesuai dengan agama yang kita anut dan juga terkadang banyak indikasi memecah persatuan dan kesatuan bangsa Indonesia.

Untuk ityu saebagai orang tuan dan guru harus banyak mengajarkan rasa persatuan dan kesatuan bangsa, cint tanah air, toleransi beragama agar tidak mudah terprofokasi dengan isu-isu yang menginginkan perpecahan.

Keterlibatan orang tua dalam pendidikan anak dapat diidentifikasi dalam beberapa pola seperti kerjasama orang tua dan anak ketika di rumah misalnya, membantu pekerjaan rumah, bersihbersih rumah, menyiram tanaman, membantu memasak, sedangkan kegiatan berbasis sekolah misalnya, menghadiri acara sekolah, menanyakan pada guru kehadiran anaknya, saling berkomunikasi tentang pelajaran di sekolah, serta pemantauan perilaku anak-anak di luar sekolah.

Untuk itu peran guru sangat mendominasi dalam dunia pendidikan. Di lembaga - lembaga pendidikan, Ada sekolah favorit sehingga muridnya banyak sampai ruang kelas tidak mencukupi dan ada juga sekolah yang di marger karena sarana prasaran serta gurunya dianggap belum kompeten atau tidak sesuai dengan jurusan dalam mengajarnya, sehingga dari berbagai kalangan menganggap belum mampu melahirkan alumni yang berkualitas. Pendidikan disekolah belum sepenuhnya menghasilkan insan-insan terdidik dan beretika (Suardana, 2020)

Apalagi di era pandemi covid-19 saat ini yang semua harus dituntut untuk belajar dari rumah, dari sini tugas guru semakin berat harus dapat menciptakan dan membangun pembelajaran yang menarik meski pembelajaran di lakukan secara daring/ Online tidak tatap muka. Hal ini menjadi tantangan bagi setiap guru agar dapat menciptakan dan membangun kreatifitas peserta didik dalam masa pandemi saat ini. Pembelajaran daring, tentu akan sulit dilakukan jika tidak ada pendampingan dari pihak keluarga untuk itu di masa pandemi covid- 19 ini orang tua dan guru harus bersinergi dalam membimbing anak-anak mereka. Guru dan orang tua harus mampu meningkatkan keaktifan dan kreativitas siswa di masa pandemi covid-19. Keaktifan dan kreatifitas siswa dapat tercipta melalui penerapan media pembelajaran yang menarik. Dengan banyaknya aplikasi yang sudah tersedia dalam HP android, Laptob, maupun komputer merupakan salah satu media pembelajaran yang menarik dalam pembelajaran daring dengan melalui via zoom, google classroom, dan lain sebagainya.

Kerjasama orang tua dan guru dalam membangun kreativitas siswa kelas 4 melalui pembelajaran daring di MI.Miftahul Ulum Tambakrejo - Tongas - Probolinggo sangat penting dalam kehidupan sehari-hari karena dapat termotivasi belajar lebih giat lagi dan lebih meningkatkan ketrampilan mereka dalam menghadapi masa depan di tengah wabah pandemi covid-19 dan dengan kerjasama juga menunjukkan keberhasilan pendidikan anak-anak mereka karena dengan mengadakan kerjasama anak-anak kita lebih terarah pola pikirnya meski masih pada tingkat Madrasah Ibtidaiyah/ 
Sekolah Dasar. Diantara kerjasma itu antara lain berkomunikasi melalui HP (telp, wa, sms, videocall), saling mengadakan kunjungan rumah (home visit)dari pihak wali murid dan guru kelas 4, mengadakan pertemuan setiap seminggu atau dua minggu sekali dan ada juga yang hampir tiap hari kerumah guru kelas 4 karena rumahnya berdekatan dengan guru kelas 4 , orng tua selalu mendampingi kegiatan pembelajaran daring/ Onine siswa sehingga menambah semangat anak- anak kita agar tidak jenuh dan bermain game saaja.

\section{DAFTAR PUSTAKA}

Abidin, Z., Rumansyah, \& Arizona, K. (2020). Pembelajaran Online Berbasis Proyek Salah Satu Solusi Kegiatan Belajar Mengajar Di Tengah Pandemi Covid-19. Jurnal Ilmiah Profesi Pendidikan, 5(1), 64-70. https://doi.org/10.29303/jipp.v5i1.111

Ayubi, S. Al. (2020). Konsep Perkuliahan Daring Google Classroom. 13(2), 106-131.

Departemen agama R.I, 1996. Pedoman kegiatan Belajar dan mengajar. Depag. Jakarta.hal 2

Daradjat, zakiyah.2000. Ilmu Pendidikan bIslam.Aksara .Jakarta.hal.76

Issa, J. (2019). No TitleE $\Lambda$ ENH. Permenkes Nomor 7 Tahun 2019 Tentang Kesehatan Lingkungan Rumah Sakit, 8(5), 55.

Issa, J. (2020). No TitleE $\Lambda$ ENH. Handbook of Medical Image Computing and Computer Assisted Intervention, 8(5), 55

Mumu, M., Majid, a, \& Rohyana, A. (2019). Hubungan Kualitas Kerja Sama Sekolah Dan Orang Tua Dengan Intensitas Usaha Belajar Siswa Di Smp Negeri Kota Tasikmalaya. Jurnal METAEDUKASI, 1(1), 37-51.

Meria, Aziza, 'Model Pembelajaran Agama Islam Bagi Anak Tunagrahita Di SDLB YPPLB Padang Sumatera Barat', 11.2 (2015), 355-80

Nurhayati, E. (2020). Meningkatkan keaktifan siswa dalam pembelajaran daring melalui media game edukasi Quiziz pada masa pencegahan penyebaran Covid-19. Jurnal Paedagogy, 7(3), 145-150.

Solviana, M. D. (2020). Pemanfaatan Teknologi Pendidikan di Masa Pandemi Covid-19: Penggunaan Fitur Gamifikasi Daring di Universitas Muhammadiyah Pringsewu Lampung. AlJahiz: Journal of Biology Education Research, 1(1), 1-14.

Suardana, I. M. (2020). AJARAN CATUR GURU. 20(20), 85-91.

Sujadi, S. A. W. dan A. A. (2015). Analisis Kesalahan Mahasiswa Dalam Memecahkan Masalah Trigonometri. SOSIOHUMANIORA: Jurnal Ilmiah Ilmu Sosial Dan Humaniora, 1(1), 51-63. https://doi.org/10.30738/sosio.v1i1.518

Khoirrosyid Oktifuadi, 'No Title No Title', Journal of Chemical Information and Modeling, 53.9 (2018), 1689-99 <https://doi.org/10.1017/CBO9781107415324.004>.

Thomas Gordon.1984. Menjadi Orang Tua Efektif. Jakarta. PT Gramedia hal 13 